\title{
The dialogic educational pathway as a strategy of care with elderly women in sexuality
}

\author{
O percurso educativo dialógico como estratégia de cuidado em sexualidade com idosas
} El percurso educativo dialógico como estrategia de cuidado con mujeres mayores en sexualidad

Daysi Mara Murio Ribeiro Rodrigues ${ }^{1}$ Célia Maria Gomes Labegalini ${ }^{1}$ (D) leda Harumi Higarashi ${ }^{1}$ Ivonete Teresinha Schülter Buss Heidemann ${ }^{2}$ Vanessa Denardi Antoniassi Baldissera ${ }^{1}$

1. Universidade Estadual de Maringá. Maringá, PR, Brazil.

2. Universidade Federal de Santa Catarina. Florianópolis, SC, Brazil.
Corresponding author:

Célia Maria Gomes Labegalini.

E-mail: celia-labegalini-@hotmail.com

Submitted on 12/09/2017.

Accepted on 01/08/2018.

DOI: 10.1590/2177-9465-EAN-2017-0388

\section{Abstract}

Objective: Unveiling the critical knowledge mediated by a care-educational dialogic pathway in sexuality with elderly women. Method: Qualitative and participatory study, outlined in educational action research approach, for which it was anchored in the Paulo Freire's Research Itinerary. 15 elderly women from a group of socialization participated in the study. Three ethical precepts were followed. Results: It was evident that the women of this study had difficulty in conceptualizing sexuality, reducing the concept to sex. In addition to diverging sexuality for men and women and configuring it as a practice of the youth. Conclusion and implications for practice: Dialogic educational activity proved to be an important care tool, since it allowed the unleashing of prejudice concerning sexuality in Aging, promoting elderly health and showing new ways of care.

Keywords: Health education; Sexuality; Aging; Women.

\section{Resumo}

Objetivo: Desvelar o conhecimento crítico mediado por um percurso cuidativo-educativo dialógico em sexualidade com mulheres idosas. Método: Estudo qualitativo e participativo, delineado na abordagem de pesquisa-ação educativa, para isso ancorou-se no Itinerário de Pesquisa de Freire. Participaram do estudo 15 idosas integrantes de um grupo de socialização. Seguiram-se os preceitos éticos vigentes. Resultados: Evidenciou-se que as mulheres deste estudo possuíam dificuldade em conceituar sexualidade, reduzindo o conceito a sexo. Além de divergir a sexualidade para homens e mulheres, e configurá-la como prática da juventude. Conclusão e implicações para a prática: A atividade educativa dialógica mostrou-se como importante ferramenta de cuidado, pois permitiu desatar as amarras do preconceito relativo à sexualidade no envelhecimento, promover a saúde das idosas e demostrar novas formas de cuidar.

Palavras-chave: Educação em saúde; Sexualidade; Envelhecimento; Mulheres.

\section{Resumen}

Objetivo: Revelar el conocimiento crítico mediado por una trayectoria cuidativa-educativa en sexualidad con mujeres mayores. Método: Estudio cualitativo y participativo, projetado en el enfoque de investigación acción-educativa, pues se ancla en el itinerario de investigación de Freire. Participaron de los estudios 15 ancianas integrantes de un grupo de socialización. Siguieron los preceptos éticos. Resultados: Las mujeres de este estudio tuvieron dificultad para conceptualizar la sexualidad, reduciendo el concepto al sexo. Además de divergir la sexualidad para hombres y mujeres, y configurarla como una práctica de la juventud. Conclusión e implicaciones para la práctica: La actividad educativa dialógica se mostró como importante herramienta de cuidado, pues permitió desatar las cadenas de los prejuicios sobre la sexualidad en el envejecimiento, promover la salud de ancianos y demostrar nuevas formas de cuidar.

Palabras clave: Educación en salud; Sexualidad; Envejecimiento; Las mujeres. 


\section{INTRODUCTION}

Discussions around sexuality, although still fraught with prejudices and prohibitions, have long evoked power relations and denounced strategies of control of the individual and of the population, a characteristic of modern society. ${ }^{1}$ It turns out, however, that control and power are asymmetrical in gender relations and sexuality is a strong ally in the normalization of female conduct in all age groups, mediated by the control of man. $^{2}$

Regarding elderly women, the domestication of female behavior in the past decades must be considered, coupled with the conception that the elderlies are asexual. ${ }^{3}$ This reality implies insufficient health care in this area and needs to be overcome, since sexuality in aging is usually neglected by health professionals due to the lack of preparation and appreciation of the young, healthy and sexually active body in our culture reinforcement for the prejudice towards sexuality in aging as well as its wider understanding..$^{3-5}$

Currently, this scenario makes it evident and necessary the insertion of health actions that contemplate a positive view on aging, ${ }^{6,7}$ among which nursing care is highlighted, in which educational practices are inherent. In this context, the dialogic and emancipatory approaches to health education are configured as innovative care strategies because they are a health promotion tool. ${ }^{7}$

In this direction, Paulo Freire's dialogical conceptions can subsidize the nursing, educational and pedagogical process ${ }^{8}$ in proposing libertarian educational actions, based on authentic dialogue, as an act of freedom ${ }^{9}$ as opposed to the manipulation and imposition of conceptions of sexuality and aging.

It should be noted that dialogue is the meeting between people who are in solidarity and reflection and act to transform their world, overcoming oppression. ${ }^{9}$ Thus, it subsidizes the preventive and educational practice in critical and transformative health, and when directed to health promotion, as in sexuality, it presents itself as the new perspective of care and is prioritized in the current public health policies, ${ }^{10}$ corroborating the premises of active aging.

In this context, educational practice is an integral part of health care, especially nursing, and it aims at the shared construction of knowledge about the health-disease-careeducation process. ${ }^{8}$

In the context of sexuality, it must be recognized as a basic human need and therefore contemplated by nursing care ${ }^{8}$ in an inseparable way of care and education. If it is based on critical and emancipatory education, the care-education process in sexuality should return to the elaboration and strengthening of complicity between professionals and users, in order to assure individuals the right to decide which strategies are the most appropriate to care for, promote, maintain and recover their health. ${ }^{11}$

Thus, seeking new horizons of nursing care with elderly women becomes essential for their emancipation and quality of life. It is believed that this can be due to the critical and liberating educational practice, ${ }^{9}$ capable of breaking with the prejudice linked to the theme of sexuality in aging.

Therefore, this study had as a research question: How could the definition of the content of the dialogue occur to collaborate with the critical knowledge of older women regarding sexuality in aging? In order to do so, the objective was to unveil critical knowledge mediated by a care-educational dialogical course in sexuality with elderly women.

\section{METHOD}

Qualitative and participatory study, mediated by educational action research ${ }^{12}$ and delineated by Paulo Freire's Research Itinerary, ${ }^{9}$ composed of the phases: thematic research; coding/ decoding; and critical unveiling in four Culture Circles (CC).

Research -a component of research- has been linked in every process to the educational practice in sexuality- a component of action. Thus, effective participation of elderly women and researchers in the target problem -sexuality in agingwas ensured in a cooperative and participative way, ${ }^{12}$ broadening in a collective and dialogic way the seriousness of the issue.

The study was conducted in a socialization group for senior citizens of a small municipality in the northwest of Paraná State, Brazil. The choice was intentional, since the previous contact of the researchers, since November 2012, allowed to observe the need for educational practices related to sexuality, because it is a theme criticized by the participants.

For this study, women who met the following criteria were included: 1) being a participant in the socialization group for the elderlies; 2) being an elderly, that is, being 60 years old or older; 3) having mental conditions to respond to the interview, measured by the Mini Mental State Examination; and 4) agreeing to participate in the study meetings.

The group had on average 52 women, nine of whom were not eligible for the present study because they were not elderly. Of the 43 women aged 60 or over, 15 accepted to participate in the study and all of these participants met the inclusion criteria.

Through Paulo Freire's Research Itinerary (Figure 1), the problematizing educational activities based on the historical character and historicity of sexuality, contextualized in the experiences of the group to promote efficient, dialogic and emancipatory communication. ${ }^{9}$

It is important to say that the research and action phases, as well as those of the Paulo Freire's Research Itinerary, stand in the development of CC. ${ }^{9}$ The methodological course is described in the following figure in order to present it, but this is complex and sometimes delineates the phases concomitantly.

Research phase began in the thematic research, which occurred in two complementary moments: the semi-structured interviews and a CC. ${ }^{9}$

The interviews were scheduled, performed by the researcher at the residence of the elderly women at a time defined by them. They occurred between April and May of 2014, with an average duration of 30 minutes and were recorded by a cellular device with the program Easy Voice Recorder ${ }^{\circledR}$ and transcribed in full. 
Figure 1. Methodological pathway of educational research-dialogical action, city of Maringá-Paraná State, 2014. Source: the authors (2017).

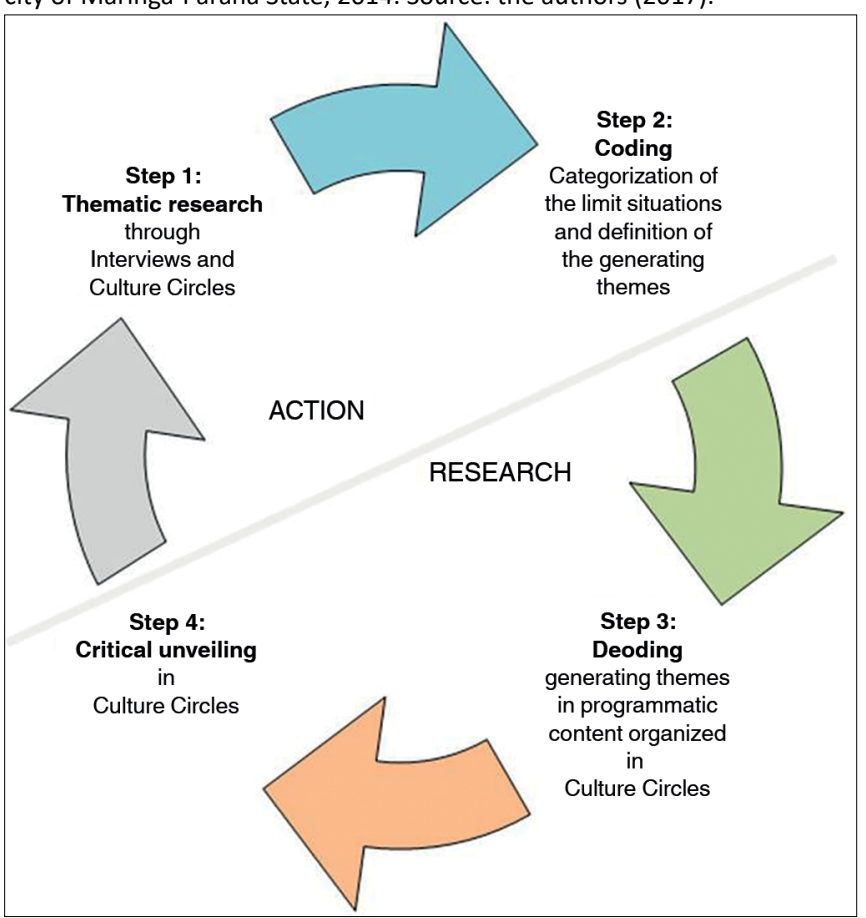

Limit situations emerged from these interviews - conceived as objective realities that result in men's perception of their problems or their reality, in a given historical moment. ${ }^{9,13}$ These situations are usually recognized by people and need to be changed by them in communion, to overcome old paradigms, ${ }^{13}$ in other words, the perceptions of elderlies at that time on sexuality which could be modified for their experience free of prejudice and interdictions. It was followed for the election of generative themes ${ }^{9}$ that would constitute the programmatic content of the educational action developed in four CC.

It is important to highlight that CCs integrate the research and action phases, concomitantly, and are spaces for collective learning, in this way, one learns in "reciprocity of consciences". In this context, researchers and people researched become actors-researchers who share knowledge and practices and construct new conceptions and postures, surpassing the naive conscience, thus critically promoting autonomy and empowerment. $^{9}$

The purpose of the first CC was to validate boundary situations and generating themes, confirming them through authentic and participatory dialogue, and defining the programmatic contents of other CCs. It began with the dynamic called Construction of the Contract, ${ }^{14: 25}$ in order to make a contract of coexistence between the participants, defining: the schedule of the subsequent meetings; the choice of the name of the group; the dynamics and organization of the group; and activities/actions that would or would not happen.
For the validation and immersion in the limit situations, the theme sexuality was presented through posters scattered around the room with phrases extracted from the interviews without any mention to the declarant. As of this moment, we began to reflect on the present, existential and concrete situation, considering the set of aspirations of the group through which one could organize the programmatic content of education, ${ }^{9}$ listing the themes that generated each boundary situation.

The clarification of the generative themes, or significant themes contained in the minimal thematic universe, that is, the subthemes of sexuality, involved in their perception that should be dialogued through other CCs, were essential to understand the reality in the perspective. It is necessary to affirm that during this dialogical moment it was already possible the insertion of the participants in a critical way of (re) thinking their world. ${ }^{9}$

Thus, in view of the generating themes, the Coding/Decoding of the programmatic contents which served as subsidies for the next CC were held. Three further CCs were carried out to break the boundary situations and empower older women to experience their sexuality, freely and autonomously. For this, they were used as educational strategies: group dynamics and videos that stimulated the Critical unveiling of all themes that permeate the universe of elderlies.

$\mathrm{CCs}$ had an average duration of 57 minutes and were recorded by a Panasonic ${ }^{\circledR}$ recorder, aided by Field Diary where the researcher can record their perceptions about the participants' dialogicity and criticality, highlighting the points of greatest interest for the subject in focus.

The study was developed under the Resolution 466/2012 of the National Health Council, with ethical assessment $\mathrm{n}^{\circ}$ 615.632/2014 (CAAE: 26890314.0.0000.0104). Participants expressed their consent by means of a Free and Clarified Consent Term and were renamed with the name of flowers, chosen by them, to guarantee anonymity and confidentiality.

\section{RESULTS}

\section{Characterization of participants}

The mean age of the 15 study participants was 66 years, ranging from 60 to 74 years. Family income ranged from one to six salaries (average of three minimum wages). The education level was 6.4 years, on average. As for marital status: eight women were married, four widows and three divorced. Ten participants reported having an active sex life. Participation time in the socialization group ranged from one to five years.

\section{Educational pathway}

In the thematic research, the participants' statements outlined the limiting situations and generating themes, essential for the other steps of Paulo Freire's Research Itinerary, presented below.

The reports show that elderly women are fragile when conceptualizing sexuality, defining it as just the sexual act or not knowing the meaning of the word, according to reports: 
Sexuality, I don't know what it is. Sometimes we think it is, and it is not, and then we are in doubt. (Lily).

I don't know what sexuality is. (Acacia).

Sexuality is part of our lives, a couple, two, right? And it's part of life, but I've been separated for about ten years, and I don't miss sex, you know. (Amaryllis)

I think sexuality is having relationship, between me and my husband. (Fleur-de-lis)

I think sexuality is the genitals of people, and also an active sex life. (Azalea)

In this way, educational actions are necessities which could clarify the concept and broaden the view of the elderly women to their sexuality, so that they can experience it without prejudice and taboos, promoting sexual and general health. This finding defines the 'Limit Situation 1: The Unknown Universe of Sexuality'.

In addition, the women in this study expressed the divergences they perceived in issues related to the experience of sexuality by men and women:

The man feels pleasure first than the woman. I think the moment of a man's orgasm is different from the woman's. The woman has to be more caressed, more ... She has to feel more wanted, to have an orgasm; and the man is faster. (Rose)

I think men and women are different, in the way I think, it's different. Men are more on fire. (Carnation)

I do not know, it's easier for men, it heats up faster. (Sunflower)

Men are different (laughs). Women love, men use women(laughs). (Tulip)

The attributions, limits and rights of men and women are biased - distinct in society, especially in Brazil. Sexuality, pleasure and relationship are the most evident, and have been used for centuries as a form of control and domination of women, thus emerging 'Limit Situation 2: The divergence of sexuality by men and women'.

In addition to gender bias, the age group is a form of normalization, and elderlies suffer from pejorative social impositions that devalue them, especially in Western societies. In this way, the participants have as reference - for sexuality -young women who have been once, while, as old women, they use the past to reinforce the concept of the present:

When my husband was alive, the sex was good. We were young. (Daisy)

Now I don't care anymore. I don't deny, I don't refuse. For me it doesn't make difference if there is sex. Bach then, it was needed; today is different. (Dahlia)
When I was younger, of course, I had more desire. I missed it more. Now, not so much. I can control myself more, I don't feel so much need for it. (Orchid)

I always hope to be like this: very calm. Not to need a man (laughs). I don't want to get a boyfriend anymore, I'm doing just fine. (Gardenia)

Elderly people are denied the pleasures of life, among them sex and sexuality. Elderlies are conceived by society and by health professionals themselves as asexual beings, since sex is associated with reproduction and healthy life, preventing older women from living their sexuality and sex in a free and healthy way, as well as discovering new ways of pleasure, configuring 'Limit Situation 3: Sex as a configuration of the youth'

The findings supported the development of planning and educational activities, in keeping with Paulo Freire's theoreticalmethodological framework, ${ }^{9,13}$ which is systematized in the following chart:

\section{DISCUSSION}

In the thematic research, the participants sought to find the limiting situations and then select the generating themes that led to the reflection of their own reality, ${ }^{9}$ especially with regard to the participants' perceptions study on sexuality in aging.

It is worth mentioning that the generative themes raised reflect the life reality of the participants, and during this process, the insertion of the research question was naturally occurring, permeating the desires and the need to express daily feelings that interfered in the way of life of the research participants. ${ }^{15}$ Therefore, the thematic research was organized in order to unveil the group's reality, to capture the participants' view on the subject to be problematized and to learn how they dealt with it in their daily lives. ${ }^{15,16}$

Nevertheless, thematic research, as a methodology, could not contradict the dialogue of liberating education. In addition, particular dialogues, in the interviews and the collective ones, in the circles of culture permeated this phase of the study. The dialogue was assumed by Paulo Freire to confirm that the thematic research "[...] is equally dialogic. Hence, in addition to being aware, it also provides, at the same time, the apprehension of the generating themes and raising awareness of the individuals around them". 9:121

The dialogue of education as a practice of freedom was inaugurated from this research, at the time of the investigation of the so-called thematic universe of the participants.

In the coding and decoding phases, we analyzed the generative themes raised, the local situations experienced by the elderlies, and opened perspectives to reflect on the problems that encompassed the whole thematic sexuality or referred to one of the elements of this issue. ${ }^{17,18}$ From this tangle of objective realities - the result of the participants' perception of sexuality in aging - the 'coding' of the generating themes found, ${ }^{9}$ or concrete existential situation, here treated as the programmatic content of the dialogue, was present. 
Chart 1. Search-action pathway following Paulo Freire's Research Itinerary, city of Maringá-Paraná State, 2014.

\begin{tabular}{|c|c|c|c|c|}
\hline \multicolumn{2}{|c|}{ Thematic research } & \multicolumn{2}{|c|}{ Coding/Decoding } & \multirow{2}{*}{ Critical Unveiling } \\
\hline Limit Situations & Generating Themes & Program Contents & Educational strategy & \\
\hline $\begin{array}{l}\text { The unknown universe of } \\
\text { sexuality }\end{array}$ & $\begin{array}{c}\text { Sexual act; } \\
\text { Sex; } \\
\text { Unaware of the theme }\end{array}$ & $\begin{array}{c}\text { Expanded concept of } \\
\text { sexuality }\end{array}$ & $\begin{array}{l}\text { Group dynamics: After } \\
\text { all, what is sexuality? } \\
\text { Objective: To understand } \\
\text { the expanded concept of } \\
\text { sexuality }\end{array}$ & $\begin{array}{c}\text { Biopsychosocial } \\
\text { perception of sexuality }\end{array}$ \\
\hline $\begin{array}{l}\text { The divergence of } \\
\text { sexuality by men and } \\
\text { women }\end{array}$ & $\begin{array}{l}\text { Men and women are } \\
\text { different; } \\
\text { Men's needs; } \\
\text { The use of the female } \\
\text { body }\end{array}$ & $\begin{array}{l}\text { Differences in sexuality } \\
\text { between men and } \\
\text { women }\end{array}$ & $\begin{array}{l}\text { Group dynamics: } \\
\text { "If I were" } \\
\text { Objective: To reflect on } \\
\text { divergences and the } \\
\text { convergences of genders }\end{array}$ & $\begin{array}{l}\text { Understanding the } \\
\text { social and psychological } \\
\text { differences of sexuality }\end{array}$ \\
\hline $\begin{array}{l}\text { Sex as a Youth } \\
\text { Configuration }\end{array}$ & $\begin{array}{l}\text { Youth; } \\
\text { I have no need; } \\
\text { Now it makes no } \\
\text { difference; } \\
\text { It's time to stop. }\end{array}$ & $\begin{array}{l}\text { Sexuality in the different } \\
\text { cycles of life } \\
\text { The configuration of } \\
\text { sexuality in the Golden } \\
\text { Age }\end{array}$ & $\begin{array}{l}\text { Videodocumentary: Love } \\
\text { and Sex in the Elderly } \\
\text { Objective: To reflect on } \\
\text { changes in sexuality in } \\
\text { the elderly }\end{array}$ & $\begin{array}{l}\text { Understanding the } \\
\text { different forms of pleasure } \\
\text { possible at any stage of life }\end{array}$ \\
\hline
\end{tabular}

Source: the authors, 2017.

It is at the moment of coding and decoding of problematized issues, starting from the context lived by elderly women, of practical examples cited by them and re-elaborated by the group, which represents a dimension of reality such as that experienced in order to elaborate the programmatic content of education., ${ }^{9,18}$ Therefore, starting from the limit situations presented and the meeting of generating themes, the coding procedure of the programmatic content of the educational action was begun, for later decoding and critical unveiling in the cultural circles that would follow. ${ }^{9}$

Since this is an action research based on the Paulo Freire's Research Itinerary, we chose to present and discuss the results from the limit situations, since they were the triggering of all educational process.

In the 'Limit Situation 1: The Unknown Universe of Sexuality' it is emphasized that sexuality is inherent to human beings, but sometimes associated only with the practice of sex, forgetting its unfolding, such as: understanding, companionship and the affectivity, indispensable at any moment of life. It can be expressed through the embrace, the touch and the affection. One must understand that pleasure exists and can be explored beyond genital sex, penetration. Changing affection is also an expression of sexuality. ${ }^{3,19}$

In this sense, it is emphasized that, because the extent of sexuality is unknown, participants report it in a reductionist and restricted way to the sexual act and to an inherent condition for the young. In the initial discussion of the theme, one can see the difficulty of verbalization on the subject, either by the absence of his construct or by shame. At that moment it was also learned that silence, as Paulo Freire said, should be understood as a topic to be brought to the discussion, because it calls for the need for overcoming difficulties.

It is possible that if sexuality had not been denied since their youth, not only now, in the Golden Age, it would be accepted with naturality. Thus, we must understand the distance between the path of socio-cultural integration and the life project of a woman, especially those who are elderlies. ${ }^{6}$

It is known that elderlies suffer the results of their biological aging, living with the natural loss of this phase, in addition to the prejudiced way about their affective relationship, loving and sexual, issued by society, including their own family. ${ }^{20}$ This prejudice can contribute, in large part, to the extinction of the practice of sexuality in the Golden Age and to the attribution of ignorance on the subject.

The way of living and conceptualizing sexuality does not arise spontaneously at this stage of life. Lifelong learning is what will define how a person will behave when being a senior. Therefore, if elderlies attribute positive values to sexuality in their youth, they will certainly live their sexuality more intensely when they reach the Golden Age, a fact that is not common among older women. ${ }^{20}$

Several factors play an important role with regard to sexuality in the Golden Age, such as people's life experiences, social level, schooling, religious and family formation. Appropriate educational interventions can help older women cope with the determinants that negatively affect their sex life, as well as broaden the concept in relation to the subject. ${ }^{20}$

Based on the statements by elderly women, the limit situation emerged and the generative themes were listed and in their 
possession the 'Expanded Concept of Sexuality' (Chart 1) was established as a programmatic content. This content was developed with the group dynamics educational strategy entitled: After all, what is sexuality? ${ }^{14}$ This activity allowed participants to immerse themselves in the thematic universe of sexuality, deepening the concept of sexuality in its biological, psychological and socio-cultural dimensions.

It was then, in the process of decoding, that it was up to the researcher, as mediator, to assist in the construction of dialogue and "challenge the elderly more and more, problematizing, on the one hand, the existential codified situation and, on the other, giving in the course of dialogue", 9:157 for later critical unveiling. Thus, for this limit situation, they critically unveiled the 'biopsychosocial perception of sexuality' (Chart 1), in which they were able to express new perceptions about the concept of sexuality, broadening the initial knowledge and breaking with sex about the sexual act. This dialogical path also allowed for a care-educational process ${ }^{8,11}$ which favored the search for and attainment of critical knowledge.

'Limit situation 2: The divergence of sexuality by men and women' refers to the historical and social construction of this theme. This asymmetrical social construction, represented by dominating men versus dominated women, establishes itself and is formed by family and society. It is precisely the patria power with the domination exerted by man on women and children in the family dynamics that founds the bases of contemporary society.

Unequal gender relations are created and the connection of the masculine is made with the idea of commanding, and of the feminine, of serving. Such a conception is extended to sexuality, with the idea of men dominating, possessing and being active, and woman being subordinate, surrendering passively. This accompanies the sexual act, in which the role of women is to serve their husbands and to procreate, and it must not involve pleasure. ${ }^{1,6}$

The reference to sexuality for this group of elderly people is that men can live it in a freer, more intense way, as a natural attribute to the masculine condition. This proves that, even after several women's achievements, the women of today still live a reflection of past experiences. In past times, women were considered sexual objects of their companions, and should always be willing and ready to satiate their wills. ${ }^{1,6}$

In the Golden Age phase, the power relations of men over women are still inserted, in which, through sexual intercourse, men assign themselves the right to have pleasure without worrying about the women's pleasure. ${ }^{16,20}$ For this, the satisfaction of their needs is of interest, and this relation is centered in the sexual act itself, specifically in the biological contact, excluding the psychological and social present in the sexuality.

The above context led to the second programmatic content: Differences in Sexuality between men and women (Chart 1). In order to discuss this content, the CC conducted the "If I were" dynamics ${ }^{14}$ introducing the discussion regarding the differences and similarities between men and women, as well as inciting discussions about gender equality and providing the elderly people of the group with the mediated dialogue in their realities.

Thus, it was perceived that the critical unveiling happened as they began to reach 'Understanding the social and psychological differences of sexuality' (Chart 1) - a fact that was apprehended by the new manifestations they made about the limit situation found in the beginning of the educational path. Once more, the dialogical educational-caring process ${ }^{8,11}$ favored criticality.

In the 'Limit Situation 3: Sex as a configuration of youth', the myth of the asexuality of the elderlies is reinforced when sex is directly related to young people and to the genital sex act still present in contemporary society. ${ }^{6}$ Sexuality in old age has been recurrently linked to negative images, from the ideas of physical degeneration, loss of sexual vigor and reproductive incapacity, among other aspects which form the western imaginary on this theme,$^{20}$ which needs to be reconstructed in a more sexuality in aging.

In fact, various transformations are suffered by the body over the years, accompanied by emotional and sexual maturation, which varies according to individual potentialities. Sexual life, as might be expected, also changes, but it can exist and remain throughout life..$^{21: 22}$

Sexuality begins to express itself differently in aging when compared to adulthood. In this phase of life it transcends the sexual act, since it includes love, affection, exchange of words and touching more expressively. ${ }^{6,22}$ In this context, two programmatic contents were defined: 1 . Sexuality in the different life cycles; 2 . The configuration of sexuality in the Golden Age (Chart 1). The CC was conducted through the presentation of a Videodocumentary, entitled Love and Sex in the Golden Age, and made possible new conceptions for old moorings that elderly people tied in their dialogue.

hence, the critical unveiling happened and was apprehended by demonstrating new 'Understanding the different forms of pleasure possible at any stage of life' and 'Freedom from prejudice regarding the verbalization of the sex theme' (Chart 1), showing the criticality in relation to thematic.

This educational-educational experience has refuted education as a directed act and normative pair. It became an exchange of experiences between teacher and student in which both expanded and reconstructed their knowledge, ${ }^{8,22}$ critically. Thus, it presented itself as an innovative process of care linked to health education for the insertion of elderly women as active in the educational process. ${ }^{8,9}$

\section{CONCLUSIONS AND IMPLICATIONS FOR PRACTICE}

This study carried out a dialogical care-education course in the thematic sexuality, with elderly women. From the thematic research it was possible to overcome the limiting situations and reach the generative themes and programmatic contents, carrying out contextualized and participatory educational practices through authentic dialogue which allowed critical unveiling. 
The dialogicity favored the unleashing of ties of sexuality prejudice in aging, as well as the construction of the expanded concept of the theme. Thus, from the abstract to the concrete, the limit situations were overcame and possibly the unpublished viable was established. It was, therefore, a process that allowed liberating education in overcoming the traditional educational approaches, which are commonly applied in nursing and that signal the need for change.

In the meantime, the applicability of this study in Primary Health Care through the Family Health Strategy in the educational groups carried out by the Family in order to develop integral and emancipatory health care is highlighted.

\section{REFERENCES}

1. Dornelles PG, Dal'Igna MC. Gender, sexuality and age: Heteronormativy in pedagogical practices of Physical Education in schools. Educ Pesqui [Internet]. 2015 Dec; [cited 2017 Dec 20]; 41(n.spe):1585-98. Available from: http://www.periodicos.usp.br/ep/article/view/109923/108420

2. Gatling M, Mills J, Lindsay D. Sex after 60 ? You've got to be joking! Senior sexuality in comedy film. J Aging Stud [Internet]. 2017; [cited 2017 Dec 22]; 40(s/n):23-8. Available from: http://daneshyari.com/article/ preview/5121674.pdf

3. Crema IL, Tilio RA, Campos MT. Repercussões da Menopausa para a Sexualidade de Idosas: Revisão Integrativa da Literatura. Psicol Ciênc Prof [Internet]. 2017; [cited 2017 Dec 21];37(3):753-69. Available from: http://www.redalyc.org/articulo.oa?id=282052994016

4. Michelin SR, Marchi JG, Hyeda IS, Heidemann ITSB, Nitschke RG. Women's perception about health promotion during the nursing consultation. Ciênc Cuid Saúde [Internet]. 2015; [cited 2018 Feb 7] 14(1):901-9. Available from: http://www.periodicos.uem.br/ojs/index. $\mathrm{php} /$ CiencCuidSaude/article/view/20300

5. Sehnem GD, Ressel LB, Junges CF, Silva FM, Barreto CN. The sexuality on nurses' academic training. Esc. Anna Nery [Internet]. 2013 jan.-mar. [cited $2017 \mathrm{dez}$ 04]; 17(1)90-6. Available from: http://eean.edu.br/ busca exibe.asp?opcao pesquisa=art\&buscar $=$ sexualidade\&offset $=20$

6. Alencar DL, Marques APO, Leal MCCL, Vieira JCM. Fatores que interferem na sexualidade de idosos: uma revisão integrativa. Ciênc Saúde Colet [Internet]. 2014 Aug; [cited 2017 Dec 3]; 19(8):3533-42. Available from: http://www.redalyc.org/articulo.oa?id=63031151024

7. Nakata PT, Costa FM, Bruzamolin CD. Nursing care for the elderly in the Family Health Strategy: integrative review. Rev Enferm UFPE On Line [Internet]. 2017 Jan; [cited 2017 Dec 21]; 11(Suppl. 1):393-402. Available from: https://periodicos.ufpe.br/revistas/revistaenfermagem/ article/viewFile/11920/14414

8. Goes TM, Polaro SHI, Gonçalves LHT. Cultivo do bem viver das pessoas idosas e tecnologia cuidativo-educacional de enfermagem. Enferm Foco [Internet]. 2016; [cited 2017 Dec 3]; 7(2):47-51. Available from: http:// revista.cofen.gov.br/index.php/enfermagem/article/view/794/319

9. Freire P. Pedagogia do Oprimido. 50ª ed. Rio de Janeiro: Paz e Terra; 2011.
10. Ferreira VF, Rocha GOR, Lopes MMB, Santos MS, Miranda SA. Educação em saúde e cidadania: revisão integrativa. Trab Educ Saúde [Internet]. 2014 May/Aug; [cited 2017 Sep 10]; 12(2):363-78. Available from: http://www.scielo.br/scielo.php?script=sci_arttext\&pid=S1981 77462014000200009\&lng=pt\&tlng=pt

11. Ilha S, Santos SSC, Backes DS, Barros EJL, Pelzer MT, Oliveira AMN. Educational and care-related (geronto) technology in Alzheimer's disease and in supporting the elderly/family: perspective of teachers and students. Esc Anna Nery [Internet]. 2017 Apr; [cited 2017 Dec 4]; 21(2):e20170039. Available from: http://www.scielo.br/scielo. php?script=sci_arttext\&pid=S1414-81452017000200211\&lng=en. DOI: http://dx.doi.org/10.5935/1414-8145.20170039

12. Thiollent M. Metodologia da pesquisa-ação. $18^{a}$ ed. São Paulo: Cortez; 2011.

13. Romo AD. Paulo Freire, o pensamento latino-americano e a luta pela libertação. Lat Am Res Ver [Internet]. 2016; [cited 2018 Feb 7]; 51(1):4361. Available from: https://muse.jhu.edu/article/617800

14. Magalhães $C$. Dinâmicas de grupo sobre sexualidade: atividades para trabalhar com adolescentes. Rio de Janeiro: Wak Editora; 2011.

15. Dominguez LJ, Barbagallo M. Ageing and sexuality. Eur Geriatr Med [Internet]. 2016 Dec; [cited 2018 Feb 6]; 7(6):512-8. Available from: https://www.sciencedirect.com/science/article/pii/S1878764916300675

16. Lumbv $M$, Roberts $S$. The inedito viavel (untested feasibility) of practitioner imaginations: Reflections on the challenges and possibilities of dialogic praxis for equity and widening participation. International Stud Widen Particip [Internet]. 2017; [cited 2018 Feb 6]; 4(1):18-33. Available from: http://nova.newcastle.edu.au/ceehe/index.php/iswp/ article/view/49

17. Oliveira SRG, Wendhausen ALP. (Re)significando a educação em saúde: dificuldades e possibilidades da Estratégia Saúde da Família. Trab Educ Saúde [Internet]. 2014 Apr; [cited 2017 Sep 21]; 12(1):129-47. Available from: http://www.scielo.br/scielo.php?script=sci_arttext\&pid=S1981 $77462014000100008 \&$ Ing=pt\&tlng=pt

18. Cook C, Schouten V, Henrickson M, Mcdonald S. Ethics, intimacy and sexuality in aged care. J Adv Nurs [Internet]. 2017 Dec; [cited 2018 Feb 6]; 73(12):3017-27. Available from: https://www.ncbi.nlm.nih.gov/ pubmed/28618054

19. Haesler E, Bauer M, Fetherstonhaugh D. Sexuality, sexual health and older people: A systematic review of research on the knowledge and attitudes of health professionals. Nurse Educ Today [Internet]. 2016 May [cited 2018 Feb 6]; 40:57-71. Available from: https://www.ncbi.nlm.nih. gov/pubmed/27125151

20. Waite LJ, Iveniuk J, Laumann EO, Mcclintock MK. Sexuality in older couples: individual and dyadic characteristics. Arch Sex Behav. [Internet] 2017 Feb; [cited 2017 Dec. 22]; 46(2):605-18. Available from: https:// www.ncbi.nlm.nih.gov/pubmed/26714683

21. Santos MC, Nunes R, Cruz GHS, Souza MS, Barbosa RAA, Lima ER, et al. Percepções e vivências de idosos sobre sua sexualidade. Almanaque multidisciplinar de pesquisa [Internet]. 2017; [cited 2017 Oct 8]; 1(1):25-36. Available from: http://publicacoes.unigranrio.br/index. php/amp/article/view/4317/2337

22. Uchôa YS, Costa DCA, Silva Junior IAP, Silva SDTSE, Freitas WMTM, Soares SCS. A sexualidade sob o olhar da pessoa idosa. Rev Bras Geriatr Gerontol [Internet]. 2016; [cited 2017 Oct 8];19(6):939-49. Available from: http://www.redalyc. org/articulo.oa?id=403849869006 